\title{
О двоякой роли письменности Великого княжества Литовского в межславянских языковых контактах
}

\author{
ЛЮДМИЛА ГАРБУЛЬ \\ Romanų kalbų katedra, Užsienio kalbų institutas, Vilniaus universitetas, \\ Universiteto g. 5, LT-01513 Vilnius \\ E-mail: liudmila.garbul@flf.vu.lt
}

(Received: 18 August 2017; accepted: 27 October 2017)

\begin{abstract}
The paper deals with the twofold role of the written language of the Great Duchy of Lithuania in inter-Slavonic, mainly Polish-Russian language contacts, based on the material of diplomatic correspondence of Muscovy. The author summarizes the research data proving that the written language of the Great Duchy of Lithuania played the role of an active mediator in the 15th-17th centuries in Polish-Russian language contacts and it was a source of lexical and semantic borrowings in the Russian written language and in the Polish written language. What is more, the paper examines anew some lexical borrowings from the written language of the Great Duchy of Lithuania in the Russian Chancery language of the 17th century as well as in the Polish language: golosovati/galasovati 'cry, make a noise; make a hubbub', navyklyj 'accustomed to, habitual' and futor/chutor 'small settlement; khutor (separated farm)'.

Keywords: inter-Slavonic language contacts, Russian, Polish, Muscovy, the Great Duchy of Lithuania, written language, lexical borrowing, semantic borrowing
\end{abstract}

Изучение польского влияния на русский язык на материале дипломатической корреспонденции Московского государства (далее МГ) конца XVI первой половины XVII вв. показало, что контакты между этими языками в большинстве случаев носили сложный характер, то есть были посредственными. Исходя из этого, не только по отношению к указанному выше периоду, но и по отношению к более длительному времени, к XV-XVIII вв., следует говорить о польско-восточнославянском языковом взаимодействии (см. ЗОЛТАН 2014: 15, ЛЕСЮв 1978: 173-179).

Итак, при польско-русском языковом взаимодействии в XV-XVIII вв. мы очень часто имеем дело со сложным контактом, при котором лексическая интерференция осуществляется через посредствующее звено. По результатам предшествующих исследований (см. ГАРБуль 2009: 45-46, 52-53) и нашим собственным наблюдениям (ГАрБуль 2009: 424-425, ГАРБуль 2014a: 253-255), в польско-русских языковых контактах XV-XVII вв. роль весьма активного посредника играла письменность Великого княжества Литовского (далее ВКЛ) - канцелярский язык и / или «простая мова». Так, в частности, по нашим данным, при заимствовании почти 1000 лексических и более 330 семантических полонизмов, выявленных в дипломатических документах МГ, в более чем $80 \%$ случаев в роли посредника, вероятнее всего, выступали актовый язык ВКЛ и /или «простая мова» (см. ГАРБУль 2014a: 252-254, ГАРБУль 2015а: 15, ГАРБУЛь 2009: 422, 425, ГАРБУЛь 2014b: 75, ГАРБУль 2016: 52). Вместе с тем 
письменность ВКЛ была не только активным посредником в польско-русских языковых контактах, но и играла роль донора. На эту роль делового языка ВКЛ в межславянских языковых контактах обращает внимание венгерский славист А. Золтан, который исследовал проблему взаимодействия в XV-XVI вв. восточнославянских деловых языков - западнорусского и великорусского - в области лексики и установил, что «...наряду с полонизмами... вошли в русский язык также собственно западнорусские (украинские и / или белорусские) слова» (ЗолтАн 1983: 342-343).

Полученные нами данные подтверждают выводы А. Золтана и позволяют дополнить представленный им перечень заимствований из письменных источников ВКЛ в русском языке (см. ЗолтАН 2014: 46-152). Так, по нашему мнению, лексическими заимствованиями из письменности ВКЛ являются следующие слова, обнаруженные в документации Посольского приказа первой половины XVII в.: баламуть / боламуть 'тот, кто сбивает с толку; смутьян' (ГАРБуль 2014a: 211-212), будникъ 'крестьянин, приписанный к будному стану, майдану (поташному, смолокуренному, селятряному производству)' (ГАРБуль 2014a: 214), будный в составе сочетания будный станъ 'поташное, смолокуренное или селитряное заведение в лесу и селение при нем' (ГАРБУль 2014a: 214), волока 'мера (или участок) земли, принятая в ВКЛ и Западной Руси (приблизительно) 16,8-21 га' (ГАРБуль 2010: 79-81), выnycтошити 'опустошить' (ГАРБУль 2010: 81-83), выразумъти / выразумети 'понять что-л. вполне, постигнуть умом, уразуметь; узнать, выяснить' (ГАРьуль 2010: 83-86), возможно, высвобожати 'избавлять от неволи, чьей-л. власти и т. п.; освобождать' (ГАРьуль 2015а: 5-6), запровадити 'отправить, отослать; препроводить' (ГАРБуль 2014а: 219-220), капщзизна 'подать на право изготавливать хмельные напитки и торговать ими' (ГАРБуль 2014a: 222-223), князство 'область, управляемая владетельным князем' (ГАрьуль 2014a: 225-226), лъсничий /лесничий 'должностное лицо, ведающее охраной лесов; управляющий королевскими лесами (королевскими поместьями) в Польско-Литовском государстве' (ГАРБуль 2014а: 232), нарушивати 'преступать, не соблюдать что-л. условленное, установленное; поступать вопреки чему-л.' (ГАРБуль 2010: 86-87), нарушитися 'оказаться невыполненным, несоблюденными (о чем-л. условленном, установленном)' (ГАРБуль 2010: 87-89), повинность 'вина; причина, источник чего-л. (неблагоприятного)' (ГАРБуль 2014a: 237), порода 'семья, род, родня; происхождение (принадлежность по рождению к какой-л. социальной группе, роду, местности); врожденные, связанные с происхождением черты внешности, характера (физический облик, совокупность всех психических, духовных свойств человека, обнаруживающихся в его поведении)' (ГАРьУль 2017), прирадити 'дать совет, посоветовать, порекомендовать; посоветоваться, принять общее решение' (ГАРБуль 2014a: 241). Лексемы бо 'ведь, ибо, потому что, так как (в начале придаточного предложения)' (ГАРБуль 2014а: 213-214), вол(b)но '(в знач. предикат.) можно, позволительно, не возбраняется, разрешается’ (ГАРБуль 2014b: 66-67), заживати 'употреблять, использовать, применять что-л.; пользоваться чем-л.' (ГАРБУль 2014b: 70-71), 
княжство 'область, управляемая владетельным князем' (ГАРБуль 2014a: 225226) и сил(ь)никь 'насильник, грабитель, притеснитель' (ГАРБУль 2017) в приведенных значениях, вероятнее всего, являются семантическими заимствованиями из того же источника.

Кроме того, не исключено, что письменность ВКЛ служила источником заимствований не только для русского, но и для польского языка. На наш взгляд, заимствованиями из письменности ВКЛ в польском языке XV-XVIII вв. можно считать слова bałamut (ГАРБУль 2014a: 212), wypustoszyć (ГАРБУль 2010: 83, 89), wyrozumieć (ГАРБУль 2010: 85-86, 89), kapszczyzna (ГАРБУль 2014a: 223), leśniczy (ГАРБуль 2014a: 232), naruszyć się (ГАРБуль 2010: 88-89). ${ }^{1}$

В этой публикации мы хотели бы пополнить список возможных заимствований из письменных языков ВКЛ в другие славянские языки, с которыми в XV-XVII вв. осуществлялись наиболее интенсивные контакты. Рассмотрим историю трех лексем, потенциальным источником которых в русском и польском письменных языках, возможно, является письменность ВКЛ.

Голосовати $[1]^{2}$ несов. Кричать, шуметь; галдеть: «И послы де и о тъхь маршалковыхъ рьчђхъ не дбаютъ: голосовавъ много, разошлись ни съ чЂмъ» ${ }^{3}$ (АЮЗР 3: 406 [301], 1649 г.).

Мы обнаружили этот глагол в дипломатическом документе, представляющем собой Записку о въcmbxъ, которые были добыты дьяком Григорием Кунаковым в бытность его в Польше в 1649 году. В интересующем нас значении голосовати не представлено в лексикографических источниках русского языка. Со второй половины XIX в. голосовать регистрируется в русской письменности в значении 'решать, избирать перевесом голосов', в котором это слово употребляется и в современном русском языке (ЧЕРных 1: 201, ДАль 1: 370, БАС 4: 254-255). По мнению В. Витковского, голосовать в этом значении является заимствованием из польского (WITKOWSKI 2006: 36).

По нашему мнению, лексема, выявленная в дипломатической корреспонденции МГ, представляет собой заимствование на слух ${ }^{4}$ глагола галасовати 'кричать, шуметь; галдеть', производного от галась 'крик; шум голосов, гам, галдеж, гвалт; суматоха; смута, волнения’ (см. BORYŚ 2005: 191, BAŃKOWSKI 1: 516). По всей вероятности, в данном случае анализируемый глагол, воспринятый на слух, был передан на письме в соответствии с орфографией слова голос, с которым была соотнесена корневая морфема.

${ }^{1}$ По мнению А. Баньковского, заимствованием из восточнославянских языков (вероятнее всего, украинского) является и лексема poroda в значении 'odmiana, rasa (bydła)' (BAŃKOwSKI 2: 705), до сих пор фиксирующееся в польских говорах (см. ГАРБУль 2017).

2 Здесь и далее цифрой в скобках указывается количество употреблений анализируемой лексемы в наших материалах.

${ }^{3}$ Усечения начала и конца цитаты не отмечаются.

4 Это предположение подтверждается и тем, что за приведенной выше цитатой из документа следует текст: «То де въ Посолской Избъ слышаль онъ Петръ Саяцкой самъ» (АЮЗР 3: 406 [301], 1649 г.). 
По поводу происхождения мотивирующего глагол существительного галасъ до сих пор нет единства мнений (обзор различных точек зрения см. SŁAWSKI 1: 397-398). В качестве одного из предположений допускается связь с праслав. *golsъ 'голос, тон; звук' и с праслав. *galati с исходным значением 'кричать', по которому перестроен вокализм формы праслав. *galasb, причем эти связи могут быть достаточно древними, хотя и внутриславянского характера (см. ЭССЯ 6: 90-91, Аникин 9: 338). Все эти образования, по-видимому, восходят к и.-е. *gol-so- или *gal-so-, 'призыв, клич', 'крик', производному с формантом или детерминативом $-s$ - от звукоподражательного корня (ЭССЯ 6: 219-220). В этимологических исследованиях указывается на возможность проникновения галасъ из одного славянского языка в другой (ЭССЯ 6: 9091, Аникин 9: 338). Большинство исследователей, рассматривавших историю этого слова, поддерживают это предположение. Однако по поводу установления направления языкового влияния высказываются диаметрально противоположные точки зрения. Так, Ф. Славский, А. Баньковский, В. Борысь, А. Е. Аникин и др. считают, что в польском языке hatas - заимствование из восточнославянских языков, вероятнее всего, из украинского (SŁAWSKI 1: 397 , BAŃkOWski 1: 516, Boryś 2005: 191, Аникин 9: 338, ЕСУМ 1: 458, ЭСБМ 3: 26). М. В. Шатэрник и А. М. Булыка относят эту лексему к заимствованиям из польского в восточнославянских языках (БулыкА 1972: 77, ЭСБМ 3: 26). Учитывая то, что постоянно происходит пополнение и обновление информации, поскольку до сих пор продолжается работа над историческими словарями славянских языков, проследим историю данного существительного в западно- и восточнославянских языках.

В памятниках польской письменности hałas в значении 'zgiełk, krzyk, wrzawa; kłótnia' известно с конца 50-х гг. XVI в., в значении 'zamieszanie, niepokój; kłopot' - с конца того же столетия, а в значении 'stuk, trzask' - с начала XVII в. (SłP XVI 8: 286, BAŃKOWSKi 1: 516, Boryś 2005: 191). В источниках XVII в. эта лексема отмечается в значении 'wrzawa, tumult, łoskot; przen. skargi, hałaśliwe pretensje’ (SłP XVII, SłPaska 1: 241). В значениях 'zgiełk, wrzawa, krzyk' и 'stuk, trzask' hałas бытовало также в польском языке XVIII-XIX вв. (LiNDE 2: 167-168, KaRŁoWICZ 2: 10). И в современном польском языке оно употребляется в значении 'nie skoordynowane głośne dźwięki, głośna, zakłócająca spokój rozmowa, krzyki, głośny stuk, trzask; zgiełk, wrzawa, harmider, rumor, stukot' (SłJP 3: 14).

В. Махек и Й. Рейзек высказывают предположение о том, что в польский hałas могло быть заимствовано из чешского языка (МАснек 1957: 122, МАCHEK 1971: 157, REJZEK 2001: 192), однако в старочешских источниках это существительное не выявлено. В словаре, регистрирующем чешский язык XIXXX вв., halas 'směsice silných hlasů; hluk, křik, rámus, hlahol' представлено (PS1JČ 1: 825, S1SJČ 2: 7). Согласно этой информации, более вероятным следует считать обратное направление влияния (SŁAWSKI 1: 397, ЕСУМ 1: 458).

Обратимся к истории анализируемой лексемы в восточнославянских языках. В письменности ВКЛ галасъ 'галас, крык, гамана' впервые фиксируется 
в 1619 г. (ГСБМ 6: 224). Более широкое распространение это существительное получает с конца 20-30-х гг. XVII в. и встречается в текстах, язык которых насыщен полонизмами (ГСБМ 6: 245, КГСБМ 2015: 149, ПГССЛ 1: 127 , СУМ XVI-XVII 6: 184). С конца 40-х гг. XVII в. галасъ наблюдается в письменных источниках также в значении 'сварка, суперечка' (СУМ XVI-XVII 6: 184). Заметим, что в историческом словаре украинского языка это слово снабжено пометой «стп. hałas» (CУM XVI-XVII 6: 184). В первом из указанных выше значений рассматриваемое существительное бытовало в белорусском (га́ласъ и гала́съ) и украинском (га́ласъ) языках в XVIII-XIX вв. (Носович 1870: 108, Тимченко 1: 169, Грінченко 1:267). В этом значении га́лас представлено в словаре современного украинского языка (СУМ 3: 444) и словаре современного белорусского языка с пометой «разм.» (ТСБМ 2: 17, ТСБЛМ 2002: 141). Что касается истории слова в русском языке, то здесь гала́съ 'голос, шум, крик' встречается в западных и южных говорах только в XIX в. (Даль 1: 341, СРНГ 6: 105).

Сопоставление хронологических данных, по нашему мнению, позволяет подтвердить предположение о заимствовании анализируемого существительного из польского в письменность ВКЛ ${ }^{5}$ и в чешский язык. В западнорусские говоры, судя по акценту, оно попало, видимо, из белорусского языка, а в южнорусские, возможно, - из украинского, вопреки В. Витковскому, который считает его непосредственным заимствованием из польского (WITKOWSKI 2006: 30).

Если же рассматривать историю производного от галасъ глагола галасовати 'кричать, шуметь; галдеть', то здесь языковое влияние могло осуществляться в противоположном направлении. Так, в памятниках ВКЛ галасовати 'галасувати, кричати' фиксируется с середины 20-30-х годов XVII в. (СУМ XVI-XVII 6: 184, ГСБМ 6: 244), далее этот глагол в значении 'кричать, шуметь' отмечается в белорусском (галасова́иъ) и украинском (галасова́ти) галасува́ти) языках XVIII-XIX вв. (см. Носович 1870: 108, Тимченко 1: 169, Грінченко 1:267). В значении ‘зчиняти галас; дуже кричати' галасува́ти употребляется и в современном украинском литературном языке (СУМ 3: 445), а также наблюдается в диалектах белорусского (галасава́иъ 'гучна крычаць') языка (ЭСБМ 3: 26).

В польских письменных источниках hałasować 'robić hałas, awanturować się' регистрируется с третьей четверти XVII в. (SłP XVII, SłPaska 1: 241) и было известно в этом значении в XVIII-XIX вв. (Linde 2: 168, KARŁOWICZ 2: 10). В современном польском языке этот глагол также бытует в значении 'robić hałas, zgiełk, głośno się zachowywać się; krzyczeć, wrzeszczeć, stukać', a

${ }^{5}$ Косвенно это подтверждается и тем, что в письменности ВКЛ в XVII в. галасъ часто употребляется в сопровождении синонимов: крикъ, окрикъ или тумул(ь)тъ 'гвалт, мітусня' (ГСБМ 6: 224, КГСБМ 2015: 149, ПГССЛ 1: 127, СУМ XVI-XVII 6: 184, ТимчЕнКо 1: 169). Кстати, тумул(b)mъ также является заимствованием из польского, но более ранним, относящимся к концу XVI в. (БулыКА 1972: 327), а поэтому, видимо, уже достаточно освоенным и, очевидно, не требовавшим пояснения в отличие от галасъ. 
значение 'robić zamieszanie, awantury, protestować' в толковом словаре снабжено пометой «przestarz.» (SłJP 3: 14-15).

Приведенная выше информация, как нам представляется, дает определенные основания для вывода о том, что глагол hatasować мог проникнуть в польский язык из письменности ВКЛ. Этого мнения придерживается и А. Баньковский (см. BAŃKOWSKI 1: 516). Из этого же источника анализируемый глагол, вероятнее всего, попал и в дипломатическую корреспонденцию МГ середины XVII в. В русской письменности XVII в. голосовати 'кричать, шуметь; галдеть' является окказионализмом, так как далее этого столетия история его пока не прослеживается.

Навыклый [1] прил. Привыкший, привычный; приученный: «Толко по навыклому прежнему обычаю королева всегда ходить изъ своихъ полать в зборную полату дворцомъ» (Якуьов 1897: 301, 1650 г.).

Это прилагательное (причастие) представляет собой производное на $-l$ от префиксального глагола (праслав. *navyknoti/*navykti 'научиться, усвоить; понять, познать', 'привыкнуть'), восходящего к имеющему общеславянское распространение и соответствия в балтийских и германских языках праслав. *vyknqti 'привыкать к чему-л., приобретать привычку, навык, умение; учиться, обучаться чему-л.', находящемуся в тесной связи с праслав. *učiti, 1 л. ед. ч. *uč ' 'учить чему-л.; приучать, прививать навык к чему-л.'

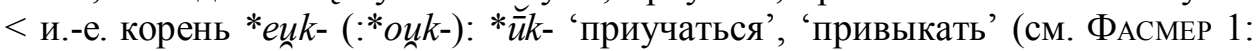
368, ФACмер 4: 179-180, Черных 2: 297, ЭССЯ 24: 46-47, Boryś 2005: 355).

Лексема навыклый выявлена нами в дипломатической корреспонденции, отражающей связи МГ со Швецией в середине XVII в., в этом документе затрагиваются также отношения первого субъекта с Польшей и ВКЛ. На данный момент этот случай является наиболее ранней фиксацией анализируемого прилагательного в русском письменном языке. В «Словаре русского языка XVIII века» оно иллюстрируется единственным примером конца первой четверти XVIII в. (СлРЯ XVIII в. 13: 149). Далее навьіклый 'пріобрьтшій навыкъ, навыкшій, искусный по опытности, по навыку' представлено в словарях, регистрирующих русский язык ХІХ в. (СЦСРЯ 2: 742, Даль 2: 389, ССОЭТ 1901: 1031), однако за пределами этого столетия судьба рассматриваемой лексемы ни в русском литературном языке, ни в его диалектах не прослеживается.

Учитывая то, что интересующее нас слово пока было обнаружено только в западно- и восточнославянских языках (см. ЭССЯ 24: 46), обратимся к его истории в тех языках, где оно, помимо русского, было засвидетельствовано. Так, в старочешских источниках прилагательное navyklý в значениях '(o člověku n. jeho orgánu) čemu, čeho navyklý, přivyklý něčemu n. na něco, mající ve zvyku něco', '(o chování, vlastnosti) navyklý, opakováním vštipený, zakořeněný' и 'obvyklý, běžný' было широко распространено уже во второй половине XV века, с того же времени встречается и однокоренное существительное navyklost 'navyklost, návyk, zvyk' и 'zvyklost, způsob života dane společnosti 
přecházející z pokolení do pokolení, obyčej' (StčS1 1: 360-361). И navyklý 'mající ve zvyku, zvyklý; navyknutý, obvyklý' и navyklost 'návyk, zvyklost' употребляются в современном чешском языке (PSIJČ 3: 286, SISJČ 3: 285).

В польской письменности середины XVI в. отмечено единичное употребление существительного nawykłość 'przyzwyczajenie, zwyczaj, nałóg' (SłP XVI 16: 443, BAŃKOwsкi 2: 280), прилагательное nawykty 'który nawykł, przywykły, przyzwyczajony', по имеющейся на данный момент информации, впервые встречается у А. Мицкевича и Ю. Словацкого (KARŁOWICZ 3: 215), из произведений которых в польский литературный язык проникли заимствования из белорусского и украинского языков. ${ }^{6}$ В словаре современного польского языка nawykly представлено следующим образом: «imesłów przeszły przymiotnikowy od czas. nawyknać; nawykty w użyciu przymiotnikowym rzad. 'taki, do którego się przywykło, przyzwyczaiło; taki, który wszedł w nawyk'» (SłJP 4: 1278). Существительное nawyktość в указанном выше значении в лексикографических источниках, регистрирующих польский язык XIX в., сопровождается пометой «mało używany», а в словарях современного польского языка пометой «daw.» (KARŁOWICZ 3: 215, SłJP 4: 1278).

В памятниках письменности ВКЛ прилагательное навыклый 'прывыклы, навучаны' и производное от него существительное навыклость 'прывычка, звычка' зарегистрированы у Ф. Скорины (СМС 1: 343-344, ГСБМ 18: 340, ПГССЛ 1: 420), который, как известно, большую часть жизни провел в различных европейских странах, в том числе и в Чехии, хорошо знал многие европейские языки и включал их элементы в свои предисловия, послесловия и в текст перевода Библии (см. ГЛБМ 1970: 85). Так, на окончательный текст «Русской Библии» значимым было влияние чешской языковой среды (см. СТАнковска 2016: 34-35). Судя по информации исторического словаря белорусского языка, прилагательное навыклый и существительное навыклость могли бытовать в письменности ВКЛ до начала XVIII века (КГСБМ 2015: 441). Далее нави́клий 'дієприкм. акт. мин. ч. до нави́кнути' и 'який увійшов у звичку, став звичним; який звик до чого-небудь' находим в словаре современного украинского языка, где последнее значение снабжено пометой «рідко» (ВТС 2005: 704). Однокоренное существительное в лексикографических источниках современного украинского языка не представлено. В белорусском языке как история анализируемого прилагательного, так и судьба существительного далее XVII в. пока не прослеживаются.

Исходя из данных об истории навыклый и навыклость в западно- и восточнославянских языках, можно, на наш взгляд, выдвинуть следующее предположение: в письменности ВКЛ обе лексемы являются богемизмами. В русский деловой язык XVII в. рассматриваемое прилагательное проникло, видимо, из письменности ВКЛ. Что касается польского языка, то nawyktość могло попасть сюда как из письменности ВКЛ, так и непосредственно из чешского языка, а nawy kty, вероятнее всего, было заимствовано из украинского, а возможно, и из белорусского языка.

${ }^{6}$ А. Мицкевич был родом из-под Новогрудка, а Ю. Словацкий - с Тернопольщины. 
Футоръ [3] м. Небольшое селение; обособленное крестьянское хозяйство с усадьбой владельца: «А резники все, так в месте яко и футорах, до единаго цеху належати будут» (ВУР 1: 174 [103], 1636 г.). «И за то де гетманъ Станиславъ Конецъ-Полской упросилъ ему у Владислава короля маетность исъ Переяславскихъ волостей село-футоръ» (АЮЗР 3: 287 [243], 1649 г.). «И Станиславова сына... наговориль просить у Богдана Хмельницкого тое маетности села-футора» (АЮЗР 3: 287 [243], 1649 г.).

В этимологическом аспекте эта лексема является неясным словом (обзор различных точек зрения о его происхождении см. ЧЕРных 2: 360-361, ФАСМЕР 4: 286-287, ЕСУМ 6: 224, ВАŃKOWSKI 1: 395). Наиболее распространенные версии его происхождения - это возможность заимствования из др.-в.-нем. huntari 'округ, район', 'сельская община', 'село', 'граница' или близкого по значению др.-Швед. hundari (ФАСМЕР 4: 286) либо из венгерского határ 'граница, рубеж' (ЕСУМ 6: 224, KaRєowicz 1: 308, ТСБМ 5: 222). Менее убедительной считается гипотеза об арабском происхождении этого слова и тюркском посредничестве при его заимствовании (ФАСмЕР 4: 286, ЧЕРных 2: 360).

Мы обнаружили слово футоръ в дипломатической корреспонденции по сношениям МГ с Польшей и ВКЛ в 30-40-е гг. XVII в. На данный момент эти случаи следует считать наиболее ранними фиксациями рассматриваемой лексемы в русском письменном языке, другие случаи ее употребления пока не установлены. В форме хутор в интересующем нас значении это существительное регистрируется в лексикографических источниках русского языка с конца XVIII в. (САР 6: 606). В словарях XIX в. ху́торь фиксируется в сопровождении помет, указывающих на областное распространение слова (см. СЦСРЯ 4: 415, ДАль 4: 569). В словарях современного русского литературного языка ху́mор не имеет ограничительных помет (ССРЛЯ 17: 528).

В связи с тем, что анализируемая лексема отмечается только в восточнославянских языках, а также в польском и чешском языках, проследим ее историю в указанных языках для того, чтобы установить пути проникновения футоръ / хуторъ в каждый из этих языков. ${ }^{7}$ Обратимся к истории слова в польском языке. В этимологических и толковых словарях польского языка указывается, что futor, chutor 'dom a. chata z ogro dem, oddalona od innych; mały folwark odosobniony, niewielkie odosobnione gospodarstwo' являются заимствованиями из украинского (см. BRÜCKNER 1974: 130, BAŃKOWSKI 1: 395, KARŁOWICZ 1: 308, 787, SłJP 1: 931, SłJP 2: 1005). В польской письменности с середины 90-х гг. XVI в. зарегистрировано единичное употребление существительного futer 'zabudowania gospodarcze; szopa z sianem w stepie do karmienia bydła zimą' (SłP XVI 7: 158, BAŃкOWSKı 1: 395). А. Брюкнер выводит futer и futro 'jadło, paszę' (с 60-х гг. XVII в.) непосредственно из немецкого Futter ‘корм; фураж’ (BRÜCKNER 1974: 130, cp. BAŃKOWSKI 1: 395, WDLP 2010).

${ }^{7}$ На истории слова chutor 'venkovské hospodářství, dvorec' в чешском языке мы не будем останавливаться специально, так как здесь оно является заимствованием, видимо, уже из современного русского языка (см. SISJČ 2: 158). 
Существительное futor 'folwarczek ukraiński (w szczerym polu, z dala ode wsi)' известно в польских источниках с начала 90-х гг. XVII в. и отмечалось также в памятниках XVIII в. (BAŃKOWSKI 1: 395, LINDE 1: 680). В словаре, отражающем польский язык XIX в., представлены и futor, и chutor 'то же', последнее засвидетельствовано со второй половины XIX в. (KARŁOWICZ 1: 308, 787, BAŃKOWSKI 1: 395). В словаре современного польского языка также находим chutor 'na wschodnim pograniczu Polski i na Ukrainie gospodarstwo wiejskie położone z dala od innych' и futor 'то же' (SłJP 1: 931, SłJP 2: 1005).

В письменности ВКЛ сначала, вероятно, появляется лексема футорь в интересующем нас значении, об этом косвенно могут свидетельствовать приведенные выше случаи ее употребления, выявленные нами в документах, где речь идет о реалиях ВКЛ, ${ }^{8}$ а также помета «старе», которой слово $\phi y-$ торъ сопровождается в этимологическом словаре украинского языка (ЕСУМ 6 : 224). Наиболее ранняя фиксация лексемы хуторъ в интересующем нас значении относится к середине 60-х гг. XVII в. (БулыкА 1972: 347, ГСБМ 36: 187, ПГССЛ 2: 452, КГСБМ 2015: 994). В словаре, регистрирующем украинский язык XVIII в., представлено футорь (Тимченко 2: 459), а в словаре, отражающем язык XIX в., находим только хýmip, xýmора 'отдъльная усадьба внь селенія, выселокъ’ (Грінченко 4: 420). В современных белорусском (ху́тар) и украинском (xýmip) литературных языках употребляется только лексема с начальным $x$ - (ТСБМ 5: 222, ТСБЛМ 2002: 726, ВТС 2005: 1553), тогда как в говорах украинского языка наблюдается и фýmip, фýmор (ЕСУМ 6: 224).

Итак, представленная выше информация, по нашему мнению, дает опре-

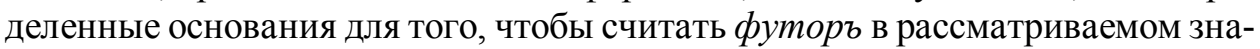
чении в русском и польском языках заимствованием из письменности ВКЛ в XVII в. При этом не исключено, что в последнюю это слово могло попасть из венгерского языка, чему не противоречат географические и исторические

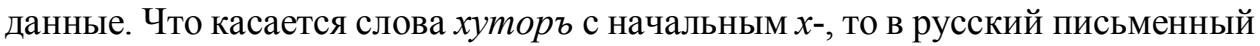
язык оно, видимо, в XVIII в. пришло из украинского языка и из того же источника проникло в польский язык в XIX в.

В заключение предлагаем некоторые обобщающие выводы:

1. Представленный выше материал подтверждает сформулированное нами положение о том, что в межславянских языковых контактах XV-XVII вв. письменность ВКЛ (канцелярский язык и / или «простая мова») выступала не только в роли посредника, но была и донором. Так, список выявленных нами ранее заимствований из письменности ВКЛ в русский приказный язык пополнился еще тремя случаями, а общее их число на данный момент составляет 19 лексических заимствований и 5 семантических калек. ${ }^{9}$ Кроме

\footnotetext{
${ }^{8}$ Данными о точной датировке футоръ в письменности ВКЛ мы не располагаем, поскольку не завершена работа над историческими словарями украинского и белорусского языков.

9 Заметим и то, что заимствования из письменности ВКЛ в XVI-XVII вв. проникали не только в русский приказный язык, но и в другие жанры письменности. Так, три лексических и одно семантическое заимствование из этого источника отмечено нами в Псалтыри 1683 г. А. Фирсова (см. ГАРБУль 2015b: 301-302).
} 
того, по нашему мнению, из того же источника было заимствовано 7 лексем в польский язык. ${ }^{10}$ Заметим, что, согласно нашим данным, в указанный период письменность ВКЛ значительно чаще выступала в роли языка-посредника, нежели была языком-донором при межславянских языковых контактах, может быть, поэтому последней роли письменных языков ВКЛ уделялось меньше внимания. Однако, на наш взгляд, изучение межславянского взаимодействия не только между группами (подгруппами) славянских языков, но и внутри самого восточнославянского ареала представляется важным и перспективным, поскольку может способствовать более полному выявлению межславянских заимствований и более точному установлению их источника, что, по мнению А. Золтана, «...имеет значение как для верификации результатов реконструкции праславянского словарного фонда...», так и для исторической лексикологии и лексикографии каждого из контактировавших славянских языков (ЗолтАН 2014: 152).

2. Результаты анализа лексем голосовати/галасовати 'кричать, шуметь; галдеть' и навыклый 'привыкший, привычный; приученный' позволяют, по нашему мнению, говорить о том, что эти внутриславянские дериваты представляют собой межславянские заимствования, а не самостоятельные образования в каждом из рассматривавшихся славянских языков. Что касается слова футоръ/хуторъ, то мы не исключали бы возможность заимствования в славянские языки из венгерского.

3. Известно, что хронологический критерий влияет на научное подтверждение факта заимствования (см. ГАрБуль 2015a: 15), а при контактировании генетически родственных языков он играет очень важную роль в установлении направления языкового влияния. В связи с этим необходимо скрупулезно регистрировать все, в том числе и окказиональные случаи заимствований, выявляемые в письменных источниках, поскольку именно эта информация может помочь установить трудно уловимую миграцию отдельных слов из одного близкородственного языка в другой.

Наш материал позволяет внести некоторые дополнения и уточнения в хронологическую характеристику анализируемых слов. Так, лексемы голосовати 'кричать, шуметь; галдеть' и футорь 'небольшое селение; обособленное крестьянское хозяйство с усадьбой владельца' отмечены в русском письменном языке впервые, а для слова навыклый существенно удревнено время его появления в русской письменности. Кроме того, наши данные позволяют скорректировать информацию о направлении языкового влияния в отношении лексемы галасъ 'крик; шум голосов, гам, галдеж, гвалт; суматоха; смута, волнения'.

4. И наконец, представленные сведения могут иметь прикладное значение: служить для дополнения и уточнения информации в этимологических и исторических словарях славянских языков.

10 Лексемы poroda 'odmiana, rasa (bydła)', chutor и nawykty были заимствованы позднее, в XIX в., из украинского языка, поэтому не включены в это число. 


\section{Источники}

АЮЗР = Акты, относящчиеся $\kappa$ истории Южной и Западной России, собранные и изданные Археографическою комиссиею. Т. 3. Санкт-Петербург, 1861.

ВУР = Воссоединение Украины с Россией. Документы и материаль. Т. 3. Москва, 1953.

Якуьов 1897 = Якуьов К. Россия и Швеция в первой половине XVII в. Сборник материалов... касающихся истории взаимных отношений России и Швеичи в 16161651 г2. Москва, 1897.

\section{Словари}

Аникин $=$ Аникин А. Е. Русский этимологический словарь. Вып. 1-11. Москва, 20072017.

БАС = Большой академический словарь русского языка. Т. 1-23. Санкт-ПетербургМосква, 2004-2014.

ВТС 2005 = Великий тлумачальний словник сучасної украӥнської мови. Уклад. і ред. В. Т. Бусел. Київ, 2005.

ГРінченко = ГРІнченко Б. Словарь украӥнської мови в чотирьох томах. Т. 1-4. Київ, 1996-1997.

ГСБМ = Гістарычны слоўнік беларускай мовы. Вып. 1-36. Мінск, 1982-2016.

ДАль = ДАль В. И. Толковый словарь живого великорусского языка. Т. 1-4. Москва, 1978-1980.

ЕСУМ = Етимологічний словник украӥнської мови. Т. 1-6. Київ, 1982-2002.

КГСБМ 2015 = БулыКА А. М. (рэд.) Кароткі гістарычны слоўнік беларускай мовы. Мінск, 2015.

Носович 1870 = Носович И. Словарь белорусского наречия. Санкт-Петербург, 1870.

ПГССЛ = БулыкА А. М. (рэд.) Падручны гістарычны слоўнік субстантыуйнай лексікі. T. 1-2. Мінск, 2013.

САР = Словарь Академии Российской. Ч. 1-6. Санкт-Петербург, 1789-1794.

СлРЯ XVIII в. = Словарь русского языка ХVIII века. Вып. 1-21. Санкт-Петербург, 1984-2015.

СМС = АнгчэнкА У. В. (рэд.) Слоўнік мовы Скарыныл. Т. 1-2. Мінск, 1977-1984.

СРНГ = Словарь русских народных говоров. Вып. 1-49. Москва-Санкт-Петербург, 1965-2016.

ССОЭТ 1901 = Чудинов А. Н. (ред.) Справочный словарь орфографический, этимологический и толковый русского литературного языка. Санкт-Петербург, 1901.

ССРЛЯ = Словарь современного русского литературного языка. Т. 1-17. Москва-Ленинград, 1950-1965.

СУМ = Словник української мови. Т. 1-6. Київ, 2010-2015.

СУМ XVI-XVII = Словник української мови XVI - першої половини XVII cm. Вип. 1-16. Львів, 1994-2013.

СЦСРЯ = Словарь иерковнославянского и русского языка. Т. 1-4. Санкт-Петербург, ${ }^{2}$ 1867-1868. [Репринт: Leipzig, 1972.]

Тимченко = Тимченко Є. К. Матеріали до словника писемної та книжної української мови XV-XVIII cm. Кн. 1-2. Київ-Нью-Йорк, 2002-2003.

ТСБЛМ 2002 = СуднІк М. 3., Крыўко М. Н. (рэд.) Тлумачальны слоўнік беларускай літаратурнай мовы. Мінск, ${ }^{3} 2002$. 
ТСБМ = Тлумачальны слоўнік беларускай мовы. Т. 1-5. Мінск, 1977-1984.

ФАСМЕР = ФАСМЕР Макс: Этимологический словарь русского языка. Т. 1-4. Москва, $1964-1973$.

ЧЕРнЫХ = ЧЕРнЫХ П. Я. Историко-этимологический словарь современного русского языка. Т. 1-2. Москва, 1999.

ЭСБМ = Этылмалагічны слоўнік беларускай мовы. Т. 1-13. Мінск, 1978-2010.

ЭССЯ = Этимологический словарь славянских языков. Вып. 1-40. Москва, 1974-2016.

BAŃKOWSKI = BAŃKOWSKI A. Etymologiczny stownik języka polskiego. T. 1-2. Warszawa, 2000.

BORYŚ 2005 = BORYŚ W. Stownik etymologiczny języka polskiego. Kraków, 2005.

BRÜCKNER 1974 = BRÜCKNER A. Stownik etymologiczny języka polskiego. Warszawa, 1974.

KarŁowiCZ = KarŁowicz J., KrYŃSKi A., NiEdźwIEDZKI W. (red.) Słownik języka polskiego. T. 1-8. Warszawa, 1900-1927.

LINDE $=$ LINDE S. B. Słownik języka polskiego. T. 1-6. Lwów, 1854-1860.

MACHEK 1957 = MACHEK V. Etymologický slovnik jazyka českého a slovenského. Praha, 1957.

MACHEK 1971 = MACHEK V. Etymologický slovnik jazyka českého. Praha, 1971.

PSIJČ = Přiruční slovnik jazyka českého. D. 1-8. Praha, 1935-1957.

REJZEK 2001 = REJZEK J. Český etymologický slovník. Voznice, 2001.

SŁAWSKI = SŁAWSKI F. Stownik etymologiczny języka polskiego. T. 1-5. Kraków, 1952-1982.

SłJP = Słownik języka polskiego. T. 1-11. Warszawa, 1958-1969.

SłP XVI = Słownik polszczyzny XVI wieku. T. 1-36. Wrocław-Warszawa-Kraków-Gdańsk, 1966-2012.

SłP XVII = Elektroniczny stownik języka polskiego XVII $i$ XVIII wieku. . http://sxvii.pl.

SłPaska = Stownik języka Jana Chryzostoma Paska. T. 1-2. Wrocław-Warszawa-Kraków, 1965-1973.

S1SJČ = Slovnik spisovného jazyka českého. D. 1-8. Praha, 1989.

StčSl = Staročeský slovnik. D. 1-3. Praha, 1977-1996.

WDLP 2010 = VINCENZ A., HENTSCHEL G. Wörterbuch der deutschen Lehnwörter in der polnischen Schrift- und Standardsprache: von den Anfängen bis in die heutige Zeit. Oldenburg: BIS-Verlag, 2010. http://www.bis.uni-oldenburg.de/bis-verlag/wdlp/.

\section{Литература}

БулыКА 1972 = БулыКА А. М. Даўнія запазычанні беларускай мовы. Мінск, 1972.

ГАРБУЛЬ 2009 = ГАРБУЛЬ Л. Семантические полонизмы в русском приказном языке первой половины XVII века. Vilnius, 2009.

ГАРБуль $2010=$ ГАРБУль Л. П. Письменность Великого княжества Литовского как источник лексических заимствований в других славянских языках. Slavistica Vilnensis 55 (2010): 77-94.

ГАРБУЛь 2014a = ГАРБУль Л. Лексические полонизмы в русском приказном языке первой половины XVII века. Vilnius, 2014.

ГАРБУЛь $2014 \mathrm{~b}=$ ГАРБУЛь Л. П. Межславянские семантические заимствования в русском приказном языке XVII века. Slavistica Vilnensis 59 (2014): 63-80.

ГАРБуль 2015a = ГАРБУль Л. П. Межславянские лексические заимствования в дипломатической корреспонденции Московского государства. Studia Slavica Hung. 60 (2015): 1-19. 
ГАРБуль $2015 b=$ ГАРБУль Л. Паратекстуальные полонизмы в Псалтыри 1683 г. в переводе Аврамия Фирсова. Studia Slavica Hung. 60 (2015): 263-307.

ГАРБУль $2016=$ ГАРБУЛь Л. П. Незамеченные семантические полонизмы в приказном языке Московского государства. Slavistica Vilnensis 61 (2016): 35-61.

ГАРБУЛь $2017=$ ГАРБУЛЬ Л. П. К вопросу о роли письменности Великого княжества Литовского в межславянских языковых контактах. Slavistica Vilnensis 62 (2017). [В печати.]

ГЛБМ 1970 = БАХАНьКОў А. Я., ЖурАЎскі А. І., СуднІк М. Р. (рэд.) Гістарычная лексікалогія беларускай мовы. Мінск, 1970.

ЗолтАН 1983 = ЗолтАН А. Некоторые аспекты польско-восточнославянских языковых контактов в области лексики. К вопросу о полонизмах в посланиях Ивана Грозного к Стефану Баторию. In: Hungaro-Slavica 1983. Budapest: Akadémiai Kiadó, Köln-Wien: Böhlau, 1983. 333-344.

ЗОлТАН 2014 = ЗОлТАН А. Interslavica. Исследования по межславянским языковым и культурныл контактам. Москва, 2014.

ЛЕСЮв 1978 = ЛЕСюв М. К проблеме польского влияния на восточнославянские языки до конца XVIII века. Acta Universitatis Palackianae Olomucensis. Philologica 40. Praha, 1978. 173-179.

СТАНКОВСКА 2016 = СТАНКОВСКА П. Русская Библия Франциска Скорины и чешская среда. Latopisy Akademii Supraskiej 7. Białystok, 2016. 29-35.

WITKOWSKI 2006 = WiTKOWSKI W. Nowy słownik zapożyczeń polskich wjęzyku rosyjskim. Kraków, ${ }^{2} 2006$. 